\title{
HERBICIDES FOR THE CONTROL OF GRASS WEEDS IN MAIZE
}

\author{
G. W. WooN \\ Ivon Watkins-Dow Ltd., Hastings
}

Summary

Trial results from the 1970-71 season for the control of summer annual growing grasses such as barnyard grass, summer grass, witch grass and yellow bristle grass in maize are presented. Cyprozine was more active on these grasses than atrazine. Most reliable season-long control was obtained with mixtures containing either cyprozine or atrazine at $2 \mathrm{lb}$ with either chloramben or propachlor. Application within 3 weeks of sowing is essential for best results.

\section{INTRODUCTION}

SINCE 1963 the standard treatment for barnyard grass (Echinochloa crusgalli) control in maize has been atrazine $4 \mathrm{lb}$ and nonionic surfactant applied as an early post-emergence band spray in combination with interrow cultivation and soil moulding over the sprayed row area (McPhail, 1968). Atrazine has continued to give good control of barnyard grass and broadleaf weeds but has shown insufficient activity towards summer grass (Digitaria sanguinalis), witchgrass (Panicum capillare) and yellow bristle grass (Setaria glauca) which have increased as a serious problem over the last two years. Pre-emergent herbicides have given variable and generally unreliable control owing to inadequate soil preparation and also dry conditions following treatment. Hence a broad spectrum herbicide or a mixture of herbicides is required which has both adequate knockdown and residual properties and is less dependent on rainfall.

Results of initial field trials with cyprozine, a post-emergent herbicide with broader spectrum control than atrazine, were reported by Woon (1970). This paper reports on a further season's evaluation of this herbicide alone and in combination with propachlor or chloramben.

\section{METHODS}

Replicated small plot broadcast applications were made with a precision sprayer, applying 20 or 30 gal of water per acre to $1 / 400$ acre plots $(15 \mathrm{ft} 6 \mathrm{in} . \times 7 \mathrm{ft})$ at 25 or $30 \mathrm{lb} / \mathrm{sq}$.in. pressure and $3 \mathrm{mph}$. Treatments were applied across the rows of maize planted at 30 in. $\times 9$ in. spacings. Visual weed control evaluations were carried out by at least two independent observers using a 0 to 10 rating scale $(0=$ no control, $10=\mathrm{com}$ plete weed control). The 0 to 10 scale was also used for assessment of crop tolerance $(0=$ completely stunted or desiccated maize, $10=$ no growth suppression and no leaf burn). At harvest the cobs from 30 plants in Trials 2 and 3 and 25 plants in Trial 1 were collected from the two centre rows, weighed and then shelled. Grain yields are expressed as bushels per acre of shelled grain adjusted to $15 \%$ moisture. Rates of application are expressed as $1 \mathrm{~b}$ active ingredient per treated acre. Atrazine was evaluated both as the standard wettable powder formulation and as an oil dispersible suspension (DS). 
Trial 1: PoKeno

Soil type: Bombay clay loam. Planted 26/10/70.

\section{Early Application}

(Treated 9/11/70)

Treatments were made to maize seedlings 2 to 3 in. high with 2 true leaves making active growth during warm weather. Broadleaf weeds were at the 1- to 2-true-leaf stage and consisted of redroot (Amaranthus hybridus) $15 \%$, black nightshade (Solanum nigrum) $10 \%$, and willow weed (Polygonum persicaria) $10 \%$. The grass weeds, witchgrass $50 \%$, barnyard grass $10 \%$ and summer grass $5 \%$ were just emerging with one true leaf. $0.2 \mathrm{in}$. of rain fell in the seven days prior to treatment, with a total of only 0.07 in. rain for the seven days following treatment.

\section{Late Application \\ (Treated $17 / 11 / 70$ )}

Maize was 5 to 7 in. in height and growing actively. Both broadleaf and grass weeds were at the 3- to 6-true-leaf stage 1 to $2 \mathrm{in}$. in height. In the first 4 days following treatment $1.75 \mathrm{in}$. of rain fell.

TRIAL 2: NgATAPA

Soil type: Gisborne sandy silt loam. Planted 28/10/70. Treated 10/11/70.

Treatments were made to maize seedlings $2 \mathrm{in}$. high under active growth conditions. Broadleaf weeds were at the 1 - to 2-true-leaf stage $1 / 2$ to $1 \mathrm{in}$. in height and consisted of $15 \%$ redroot and $5 \%$ black nightshade. The annual grass weeds were $1 / 2$ to $1 \mathrm{in}$. in height having 1 to 2 true leaves and consisted of $50 \%$ summer grass, $20 \%$ yellow bristle grass and $10 \%$ barnyard grass. 0.74 in. of rain fell in the seven days following treatment with a total of $0.95 \mathrm{in}$. falling in the next two days.

Trial 3: WaIKato

Soil type: Rukuhia peat loam. Planted 23/10/70.

\section{Early Application \\ (Treated 2/11/70)}

Maize was 1 to $2 \mathrm{in}$. in height in active growth having emerged only 2 to 3 days. A heavy infestation of weeds was present consisting of $20 \%$ broadleaf weeds of which black nightshade was dominant, and $80 \%$ annual grasses made up of $70 \%$ witchgrass and $30 \%$ summer grass. Barnyard grass had not emerged. Broadleaf weeds were at the cotyledonary stage, $1 / 4$ in. in height and the grasses had 1 true leaf and were $1 / 4 \mathrm{in}$. to $1 / 2$ in. in height with emergence not fully complete. 1.13 in. of rain fell one day prior to treatment and $0.24 \mathrm{in}$. in the following ten days.

$$
\begin{gathered}
\text { Late Application } \\
\text { (Treated 10/11/70) }
\end{gathered}
$$

Maize was 3 to 4 in. in height and had 2 to 3 true leaves. By this time barnyard grass seedlings had emerged, making up $10 \%$ of the grass weeds present. The grass had developed 2 to 3 true leaves and up to $1 / 2 \mathrm{in}$. in height. Broadleaf weeds had 2 to 4 true leaves and were up to $3 / 4$ in. in beight. 0.24 in. of rain fell in the eight days prior to treatment and $0.46 \mathrm{in}$. in the following ten days. 


\section{RESULTS}

Because broadleaf weeds were extremely well controlled by all treatments, the results and discussions refer only to the annual grass weeds present in the trials.

TRIAL 1

Results showing the control of summer grass, witch grass and barnyard grass along with maize yields are presented in Table 1.

TABLE 1: WEED CONTROL AND MAIZE YIELD, TRIAL 1

\begin{tabular}{|c|c|c|c|c|c|c|c|c|}
\hline \multirow[b]{2}{*}{$\begin{array}{l}\text { Treatment } \\
\quad(l b)\end{array}$} & \multicolumn{4}{|c|}{$\begin{array}{c}\text { Weed Control } \\
\text { Days after Treatment }\end{array}$} & \multirow{2}{*}{\multicolumn{2}{|c|}{$\begin{array}{l}\text { No. of Cobs } \\
\text { from } 30 \\
\quad \text { Plants }\end{array}$}} & \multirow{2}{*}{\multicolumn{2}{|c|}{$\begin{array}{c}\text { Yield } \\
(b u / a c)\end{array}$}} \\
\hline & early & late & early & 4 late & & & & ac) \\
\hline atra & 15 & 3.3 & 1.7 & 2 & 30 & 30 & $153 \mathrm{a}$ & 1. \\
\hline DS & & & & & 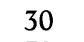 & & & \\
\hline e 2 & 6 & 7 & & 5 & 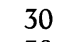 & 30 & $74 \mathrm{a}$ & \\
\hline cyprozine 4 & 8.8 & 9 & & $y$ & & 30 & 73 a & \\
\hline $\begin{array}{l}\text { propachlor } 4 \\
\text { atrazine* } 2 /\end{array}$ & 5.1 & 3.6 & 3.6 & 1.3 & 30 & 30 & $152 \mathrm{a}$ & 154 \\
\hline $\begin{array}{l}\text { chloramben } 4 \\
\text { cyprozine } 2 /\end{array}$ & 5.8 & 4.3 & 4.6 & 4.2 & 30 & 30 & $50 \mathrm{a}$ & $163 \mathrm{a}$ \\
\hline $\begin{array}{l}\text { propachlor } 4 \\
\text { cyprozine } 2 /\end{array}$ & 8.3 & 7.8 & 7.7 & 5.6 & 30 & 30 & $160 \mathrm{a}$ & $162 \mathrm{a}$ \\
\hline chloramben 4 & 9.3 & 7.8 & 8.1 & 8.7 & 30 & 30 & $0 \mathrm{a}$ & $157 \mathrm{a}$ \\
\hline $\begin{array}{l}\text { Control } \\
\mathrm{CV}-7.9 \% .\end{array}$ & 0 & 0 & 0 & 0 & 30 & 30 & & \\
\hline
\end{tabular}

*Applied with nonionic surfactant at $0.5 \%$.

Cyprozine gave adequate knockdown of grasses at both 2 and $4 \mathrm{lb}$, the $4 \mathrm{lb}$ rate giving greater residual control. Both rates gave significant yield increases over untreated control. Atrazine gave comparatively poor final grass control but still an increased yield over untreated control. Formulation of atrazine in oil increased the knockdown activity, especially at the late treatment stage when the grasses were at a more advanced stage of growth.

TABLE 2: WEED CONTROL AND MAIZE TOLERANCE AND YIELD, TRIAL 2

\begin{tabular}{|c|c|c|c|c|}
\hline $\begin{array}{l}\text { Treatment } \\
(l b)\end{array}$ & $\begin{array}{c}\text { Weed Control } \\
2 \text { wk } \\
\text { post-treatment }\end{array}$ & $\begin{array}{c}\text { Crop } \\
\text { Tolerance } \\
\text { Harvest }\end{array}$ & $\begin{array}{c}\text { Mean No. } \\
\text { Cobs }\end{array}$ & $\begin{array}{c}\text { Yield } \\
(b u / a c)\end{array}$ \\
\hline atrazine* 4 & 6.3 & 7.0 & 24 & 117.0 \\
\hline atrazine $4+$ spray oil $1 \%$ & 8.2 & 7.5 & 25 & 144.0 \\
\hline atrazine* 2 /propachlor 4 & 8.2 & 7.3 & 25 & 157.5 \\
\hline cyprozine $2.5 \quad \ldots . \quad \ldots$. & 8.5 & 8.8 & 24.7 & 166.5 \\
\hline cyprozine 3.75 & 9.2 & 8.0 & 23.7 & 170.1 \\
\hline $\begin{array}{lll}\text { Control } \ldots . . & \ldots . & \ldots \\
\text { CV }-21.6 \% . & \end{array}$ & $\ldots$ & 4.8 & 14.0 & 100.8 \\
\hline
\end{tabular}

*Applied with nonionic surfactant at $0.5 \%$. 


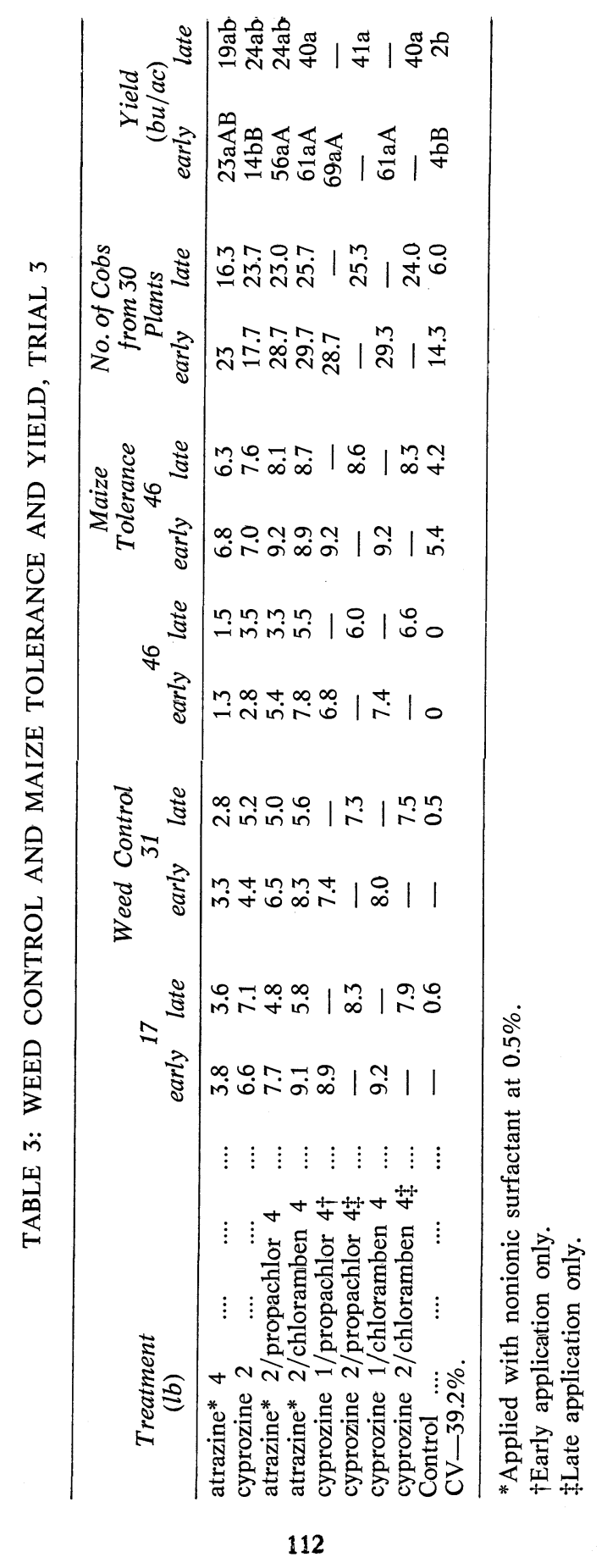


Mixtures of cyprozine with chloramben or propachlor gave considerably improved grass control over the comparable mixtures with atrazine. Mixtures containing chloramben gave superior residual control to mixtures containing propachlor, particularly in the late treatment where heavy rann followed application. In general, there has been little difference due to time of application probably because there was lack of rain following tne first treatment.

\section{TRIAL 2}

The control of summer grass, yellow bristle grass and barnyard grass together with maize tolerance and yield are presented in Table 2.

The level of control of summer grass and yellow bristle grass obtained with all herbicides except the standard applied at this early stage of treatment was satisfactory giving worthwhile yield increases over untreated control. The addition of spraying oil to atrazine gave an increase in grass control and maize yield compared with the standard treatment of atrazine with a nonionic surfactant. There was no difference in grass control or maize yield between the two rates of cyprozine.

TRIAL 3

Results showing the control of summer grass, witchgrass and barnyard grass along with maize tolerance and yield are presented in Table 3 .

Results at harvest show extremely low yields due to a very dense infestation of witchgrass growing under favourable conditions of soil moisture, temperature and high organic matter. However, it should be noted that the grower's yield in this crop was considerably higher owing to a combination of both chemical weed control and inter-row cultivation.

Cyprozine at $2 \mathrm{lb}$ gave satisfactory knockdown but no practical residual control, with atrazine also showing very limited activity. The addition of propachlor or chloramben to the triazine herbicides increased both knockdown and residual activity and substantially increased grain yields compared with the untreated control or the triazines alone. Early application of these mixtures gave increased grass control and grain yield compared with the later applications. A decrease in cob numbers occurred in the less effective treatments and in the untreated control.

\section{DISCUSSION}

In the three trials cyprozine showed much greater activity than atrazine as a "knockdown" herbicide for the control of the annual grass weeds. Rates of $4 \mathrm{lb}$ of cyprozine alone are required for complete residual season-long control without inter-row cultivation. The formulation of atrazine as an oil dispersible suspension was superior to the standard wettable powder formulation but was inferior to cyprozine.

Propachlor and chloramben at $4 \mathrm{lb}$ have both shown adequate activity against these annual grasses in combination with the triazines.

When treating summer-growing grass weeds, the timing of application is critical in obtaining maximum weed control. Applications within 12 to 18 days of sowing, irrespective of the growing conditions, give a more reliable control than treatments at a later date, particularly under heavy weed infestation.

\section{CONCLUSION}

Treatment of maize crops for grass weed control should be made within 2 weeks of sowing for maximum effect. At this time the farmer may have difficulty in identifying grass weeds at first emergence-hence a mixture 
of herbicides with both knockdown and residual properties and a broad spectrum of weed control activity is desirable.

In the trials presented, the mixtures of cyprozine $2 \mathrm{lb}$ plus either chloramben $4 \mathrm{lb}$, or plus propachlor $4 \mathrm{lb}$ were outstanding. Mixtures of atrazine $2 \mathrm{lb}$ with both chloramben and propachlor at $4 \mathrm{lb}$ also gave acceptable degree of weed control. Cyprozine showed approximately twice the herbicidal activity of the standard atrazine treatment.

Further work with these mixtures as band applications along the crop row in combination with inter-row cultivation is warranted on a wider range of soil types and varying moisture conditions.

\section{ACKNOWLEDGEMENTS}

Grateful thanks are due to the staff of the Research Division of Ivon Watkins-Dow Ltd. and the farmers who co-operated in making trial sites available.

\section{REFERENCES}

McPhail, D. D., 1968: Proc. 21st N.Z. Weed \& Pest Control Conf.: 104. Woon, G. W., 1970: Proc. 23rd N.Z. Weed \& Pest Control Conf.: 42. 